\title{
The «Learning in Depth» Proposal: Its Importance as a Science Curriculum Strand
}

\author{
Dr. Stathis Stivaktakis \\ School Counselor, Primary Education \\ Crete-Greece
}

\begin{abstract}
The Learning in Depth» idea has been proposed by educational theorist Kieran Egan. It is based on the recognition that engaging students imaginations presupposes a significant amount of knowledge. Even though a simple idea, it has nonetheless the potential to transform education, in the sense that students will have the opportunity to develop in-depth knowledge about a topic, and, at the same time, inquiry skills and their creative imagination. This paper provides a brief description of the «Learning in Depth» (LiD) proposal, and then proceeds to the task of putting it in the science education context by discussing the problem of content selection and the problem of evaluating the results of its implementation.
\end{abstract}

Keywords: Learning, Science, Self-directed inquiry, Content knowledge, Interdisciplinary knowledge.

\section{Introduction}

The «Learning in Depth» (LiD) idea has been proposed by educational theorist Kieran Egan (2011). It is based on the recognition that engaging students imaginations presupposes a significant amount of knowledge. Indeed, the more a student knows about something, the more readily a student can be imaginative about and can understand it. And if thinking presupposes knowledge, one can understand the educational and the wider significance of this proposal.

According to Egan (2011), LiD is a simple and radical program, in which students take on a specific topic about which they will build a portfolio during their schooling. They should begin with the earliest grades and continue through grade 12 .

Even though such a proposal could be for students of all ages, as it can help engage them with the subject matter, at both the elementary and high school level, those who will benefit the most, according to Egan (2011), are those of the elementary school. Such a 'preference' for the young ones can be justified on the grounds that children are by their nature curious and thirsty for knowledge. And, given the problems with science education in particular, the 
LiD proposal, in the case of school science, can very well boost engagement with science content knowledge and science in general.

In addition, however, there is another issue that can be addressed through the implementation of the LiD proposal, and this applies to all school subjects. It is the issue of how deep students' knowledge can be as a result of their exposure to the school curriculum. For it is well known that one perennial problem in curriculum development is the tension between breadth and depth. One cannot achieve both, given the practical and also the theoretical constraints imposed on the implementation of the curriculum (see Egan, 2005, 2011; Hadzigeorgiou, 1997, 2005). The LiD proposal, by its very nature (see its description in the next section), can help students go into some depth with regard to their knowledge.

Egan (2011) convincingly argues that the LiD proposal is an answer to the existing situation with students having very limited if any, opportunities to study anything in depth. The common observation about the school curriculum is that it is a mile wide and an inch deep. Schools are expected to cover a very wide range of curricular knowledge. And, as a result of this, students do not really learn enough about any topic, and rarely, if at all, have the opportunity to develop true expertise about something.

The purpose of this paper is to provide a brief description of the Learning in Depth' (LiD) proposal and then proceed to the task of putting it in the science education context by discussing the problem of content selection and the problem of evaluating the results its implementation.

\section{A description of the LiD proposal}

The 'Learning in Depth' proposal/program can follow a simple design: During the first weeks of the school year, each student is assigned (or, alternatively, I would add to Egan's proposal, the student chooses) a topic to learn in depth. Topics may be anything from rocks, icebergs, birds, airplanes, insects, ships and whales to apples, trees, the measurement of time, spaceships, rockets, stars and galaxies. The program can take only about one hour a week. After students receive their topic, they will start building their personal portfolio on it. They can be supported by their teachers, parents, and others (e.g., peers, friends).

Even though the ideal situation would involve students starting their LiD program in the kindergarten or first grade and continue with the same topic until the end of schooling (Egan, 2011), students could start at any grade of the elementary school; the sooner, the better. This continues alongside the compulsory curriculum, and the outcome is ungraded.

The primary aims of the LiD proposal are to foster student engagement with a specific topic so that students increase their knowledge about that topic. What are the pedagogical and the overall educational benefits of such an idea? It can increase students' specific knowledge about a specific topic, thus making them experts, but, at the same time, it can help students develop inquiry skills, and foster self-directed inquiry as well. Moreover, it can help them develop their imagination. Indeed, the deeper a student goes with regard to a topic (e.g., airplanes, snakes, castles, pills, stars), the more connections she or he is able to 
make, and therefore the more imaginative she or he becomes. Thus the student becomes a better thinker.

What needs to be pointed out is that LiD is not a taught program, as students determine both their workload (i.e., how many hours they are going to work per week at home) and the direction their work will take (i.e., what connections they will make and where their focus will be).

\section{The educational philosophy behind the LiD proposal}

The LiD proposal is based on a liberal philosophy of education. Even though a consensus about the main purpose of liberal education appears to exist - which is the development of free human beings who know how to use their minds and are able to think for themselves (Adler, 1982; Oakeshott, 1989, 1991; Moulakis, 1994; Peters, 1973) this purpose can be interpreted rather narrowly, and liberal education be identified with a kind of intellectualism, and even accused of being elitist. However, the purpose of liberal education is to cultivate the mind of the student so that he or she can think critically and creatively. And most importantly, to cultivate independent thinkers, who can think for themselves. The cultivation of students' mind (i.e., their critical and imaginative intellectual abilities) are to take place through their initiation into the various forms of knowledge, such as mathematics, natural sciences, literature and fine arts, philosophy, etc. (Hirst, 1974; Peters, 1973, 1998; see also Egan et al., 2014; Higgins \& Reid, 2017). Thus, from a liberal education perspective, the acquisition of content knowledge is of crucial importance.

The LiD proposal, by focusing on the in-depth study of a topic, emphasizes the development of content knowledge in a specific discipline (depending on the nature of the topic) and also in other disciplines (depending on the kind of connections that students make). And, as was said above, the acquisition of content knowledge will foster the development of thinking skills.

Gardner (2011) warned teachers and educators against implementing interdisciplinary approaches without students grasp of content knowledge. In fact, according to him, only after students have been initiated into the various disciplines does it make sense to speak of such notions as multidisciplinary and transdisciplinary knowledge. He cautioned that:

A genuine interdisciplinary approach proves to be a difficult one to achieve, and it can only be legitimately undertaken, let alone carried off with success, at a time when individuals have achieved at least some rooting in the constitutive disciplines. (Gardner, 2011, p. 104).

The crucial importance of content knowledge is supported by empirical studies in the area of science education. These studies have explored the role that content knowledge can play in making students perceive the world and school science, as a school subject, differently, as a result of learning such content (Girod et al., 2003; Pugh, 2004, 2011; Hadzigeorgiou \& Garganourakis, 2010; Hadzigeorgiou, 2012).

On the other hand, the development of the creative imagination is another aim of the liberal approach. According to Hadzigeorgiou (2014), the stimulation of the imagination facilitates thinking, and students' inquiry can very well foster the development of their creative imagination. The connections 
also that young students make when studying a LiD topic help them become more imaginative thinkers. There is evidence that supports the relationship between the development of imagination and the making of connections among objects, events, and ideas (Duffy, 2006; Louis, 2008).

What should be pointed out is that in the midst of curriculum reform proposals, over the last two decades, that have put an emphasis on instrumental and practical knowledge - especially nowadays with the focus on STEM subjects (i.e., Science, Technology, Engineering, Mathematics) - a liberal education perspective on the philosophical foundation of the school curriculum is more than welcome (Hadzigeorgiou, 2015, 2016; Zimlich, 2017). Notwithstanding the benefits of such proposals - they indeed encourage engagement with school subjects - there is a question about the scope of the curriculum (e.g., what things beyond those that can be reduced to practical knowledge students actually learn) and most importantly about whether everything that students are supposed to learn can be reduced to practical problems and applications (Hadzigeorgiou \& Konsolas, 2001; Hadzigeorgiou \& Fotinos, 2007; Hadzigeorgiou \& Stivaktakis 2008).

In addition, the educational philosophy, specifically, of science education proposals and reform agendas (e.g., science literacy, science education for sociopolitical action) are not based on an explicit educational philosophy. While one might argue, their philosophy is implicit (e.g., science education for sociopolitical action is based on a utilitarian/pragmatist philosophy), confusion surrounding the goals of the science education proposals due to lack of an explicit educational philosophy is not uncommon (i.e., scientific literacy) (Hadzigeorgiou, 2005; Hadzigeorgiou, 2017; Schulz, 2009, 2013; Hadzigeorgiou \& Stamatis, 2017).

This shortcoming and, in fact, problem, is overcome because the aims of $\mathrm{LiD}$ are clear. Indeed, the main thrust of $\mathrm{LiD}$ is the development of deeper content knowledge about a topic, and the development of inquiry skills. LiD, in my view, is the best example of a program that is about 'learning how to learn' even though there are some issues that are raised specifically for the case in which LiD is implemented in the school science context, which I will discuss in the next section.

\section{The LiD proposal in the school science education context}

It is no news that students finish their schooling with very limited detailed knowledge about any science topic. In many cases, such detailed knowledge is non-existent. And the students rarely develop any intense interest in science (Alberts, 2013). It is for these reasons that LiD in school science can provide new avenues for engagement and learning.

However, in my view, the implementation of LiD in the context of school science, presupposes that three issues have been discussed and the questions raised by them have also been adequately answered. These issues refer to: (a) topic selection and the nature of the topics, (b) student guidance, that is, the frequency student-teacher interaction and (c) the problem of what to assess with regard the impact of the LiD proposal on science learning. Apparently, these three issues and will influence the way in which $\mathrm{LiD}$ in the context of science 
will be implemented and evaluated. Certainly, there are other issues to be dealt with, such as, for example, finding curriculum time, letting students choose their specific topic, etc. However, the three issues are central and specific, I would say, to science.

With regard to the topic selection, one could move, in general, in two directions: (a) topics that are not related to those covered by the compulsory curriculum and (b) topics that are part of the compulsory curriculum. Whether we opt for the former or the latter, LiD work can be an accompaniment to the school curriculum, and, as such, can enrich and extend students' knowledge about what they are already learning or simply broaden their interests through their exposure to new ideas. In either case though students will be developing inquiry skills through self-directed and collaborative inquiry.

On the other hand, with regard to the selection process, assignment or lottery is one option, and free choice is another. This is not something that can be settled here, but the depending on age and other characteristics and parameters (e.g., students' interests, degree of parental involvement, availability of resources) both options can be considered. Egan (2011), of course, recommends the topic assignment. But I think, especially in the case of older students, that free choice may be a better option. Adoloscents, for example, in the case that LiD was to be implemented in a grade 7 classroom, despite their contradictory needs, and fleeting interest, do want to have the possibility to choose something freely.

However, it deserves to be noted that, even if one were to bypass the process of topic selection (i.e., chosen freely by each student or assigned by the teacher), there is the issue of the nature of the topics. Science is a broad area and topics could be from the life sciences, the earth sciences, the physical sciences, the space sciences. There two questions to be asked here: Should all sciences be represented equally in the 'basket' of topics from which students will pick their own topic, or some sciences (e.g. life sciences) are preferable or rather more suitable for very young students? Are, for example, life science issues and concepts more pedagogically appropriate for the lower grades students, while physical science concepts are more appropriate for the upper levels and grades? Personally, I do not agree with this kind of differentiation but I think that it is an issue to be considered and discussed.

Even though, In general, science topics can be anything from everyday familiar entities and phenomena, such as. "birds," "apples," "dust," "the measurement of time," to distant and unfamiliar ones, such as, "the solar system," sp.ace travel and "galaxies", we need to include broad areas from the outset Such areas refer to mechanics, heat and electricity, with topics such as forces, lamps, thermometers. Such topics are within the chidrens capacity to understand and then, as they progress, help them, through regular consultations and guidance, build connections and thus subsume whatever new ideas they learn under those broad topics.

In my view, depending on the educational level (e.g., lower elementary, upper elementary, junior high), LiD in Science topics can be natural phenomena, Science/Technology issues, Socio-scientific issues and/or science concepts. For the lower grades, (abstract) science concepts may not be appealing to the students. For this reason, topics at the interface of science and technology (e.g., cell-phone communication), which address anyway science concepts (e.g., in the 
cell-phone topic, the concept of the electromagnetic wave, that of energy, etc.) or socio-scientific issues appear more pedagogically appropriate.

In regard to students' guidance, some points also need to be made. Even though LiD work can result in self-directed inquiry - an important outcome from the perspective of the development of students' autonomy - teacher-student interactions are crucial from a socio-cultural perspective on teaching and learning (Vygotsky, 1978, 1997). Notwithstanding the pedagogical and educational significance of independent work through self-directed inquiry, such work, as far as the development of scientific understanding is concerned, can result in misconceptions (or naïve conceptions). So if one the goals of the $\mathrm{LiD}$ proposal in science is the development of scientific knowledge. Thus, more frequent teacher-student interactions seem necessary, in comparison with traditional LiD work. Although from the point of view of content knowledge acquisition there seems to be no difference between learning, for example, about apples, bridges, and lighthouses, on the one hand, and learning about forces, energy or atoms, on the other, conceptual knowledge, especially in the case of physical science concepts, is not easy to achieve without some guidance. Even in the case in which students choose, or are assigned «lighthouses» as their topic, conceptual knowledge of light is not something that students can do it on their own. However, this is something that can be assessed. That is, we can assess the degree in which independent work can lead to conceptual understanding. Which brings me to the issue of assessment.

The question how one can go about in order to assess the impact of $\mathrm{LiD}$ is of crucial importance, not simply because we are talking about the outcomes of learning - what things have students actually learned -but because assesment refers to a variety of outcomes, not just to knowledge if science. Indeed, what things should we look at after we start implementing the LiD programme?

All three components of the science curriculum, that is content knowledge, skills and attitudes should be assessed. This assessment process can be approached with an open mind mainly through naturalistic research designs, even though a quantitative approach is also necessary for the measurement of attitudes and learning outcomes. In this way we can also assess how LiD work aids the learning of the mandatory curriculum.

It is crucial, if we talk about LiD in the school science context, that we bear in mind that a topic that is related directly or indirectly to a science concept or phenomenon, and/or which could help develop in students an interest in the topic or the science concept per se, does not necessarily does so. For example, the topic of "lighthouses", even though it is directly related to the concept of light, and indirectly to a number of physical phenomena involving light (e.g., reflection, refraction), may very well spark an interest in travelling, poetry, sea wrecks, etc.), but not foster an inquiry into the phenomena of light. By the same token, a student cannot learn the mechanical principles of bridge design and construction by collecting in his/her portfolio photographs of bridges. In other words, students cannot learn science simply by doing, even with great enthusiasm, a number of things, but which are unrelated to science. A student, it needs to point out, cannot learn science by collecting photos of various natural phenomena, any more than she or he can understand electricity and photosynthesis, for example, by observing light bulbs and tree leaves 
respectively.

I also think that impact of content knowledge acquisition on learning science should also be assessed. In fact, such impact can be the main objective of assessment, as the main thrust of LiD, as an educational innovation is the acquisition of detailed knowledge.

It deserves to be pointed out though that before a large scale implementation of $\mathrm{LiD}$ in science education takes place we need to explore several things, some of which have not been researched before. For example, the effect of content knowledge acquisition on student motivation and on learning has not been studied in general or specifically in they field of school science education. So with regard to implications for research, according to Hadzigeorgiou (personal communication, April 2016), we need to answer the following research questions:

- Does participation in the LiD programme foster the development of scientific knowledge and understanding?

- Does the acquisition of science content knowledge increase engagement with science and in what ways?

- What effect does knowledge of a specific topic have on students' overall curricular progress?

- To what extend do students become creative thinkers?

- To what extent does topic investigation promote self-directed inquiry?

- What kind of curricular connections do students actually make through their inquiry?

- To what extend do students promote their knowledge of STEM subjects?

- Does acquisition of science content knowledge transform and in what ways students' view of the nature science and the nature of scientific knowledge?

- Does LiD in science promote a transformative kind of learning?

\section{Conclusion and Final Comments}

The LiD proposal has the potential to transform school learning and education in general. Its implementation in the context of school science can help with the achievement of significant educational goals, such as autonomous learning, creativity, inquiry skills, and, of course, in-depth knowledge about a science topic.

We certainly need to trial LiD, as was already discussed, given that science learning refers to factual and conceptual knowledge, as well as knowledge about the nature of science, science process skills, and attitudes. However, its potential is undisputed, as the discussion in this paper has tried to show. Moreover, Lid work, in the case of very young children, even preschool children, does not violate pedagogically appropriate practices (Hadzigeorgiou, 2001, 2002; Hadzigeorgiou et al., 2009; Barry \& Raftery, 2016).

Ever since I became familiar with $\mathrm{LiD}$, after Professor Hadzigeorgiou, of the University of the Aegean, made a presentation in my school district, I realized the potential of $\mathrm{LiD}$ as a curriculum, especially science curriculum, strand. I strongly believe that teachers should become familiar with the LiD programme and should find a curriculum slot in order to implement it in their classrooms. 
If ours is an age of learning, as Pugh (2107) argues - not simply, or only, information or knowledge age - LiD can play a crucial role in young students' learning process. And, at the same time, help foster, through their (students') inquiry and research, inquiring minds that are thirsty for learning. Pugh (2017) makes reference to Richard Feynman's love and in fact passion for learning. However, even though many students are not like Feynman, for a number of reasons, who would argue against Pugh's view that "The world needs more Richard Feynmans" or, perhaps, that "we all need a bit more Feynman in us" (Pugh. 2017, p.3)? The challenge today, I believe, is to foster learning in all students, and this challenge should be taken by elementary school teachers. LiD, by its very conception by educational theorist Kieran Egan, can be an indispensable tool that can help teachers meet this challenge.

\section{References}

Alberts, B. (2013). Prioritizing science education. Science. 340, 249. https:// doi.org/10.1126/science.1239041

Adler, M. J. (1982). The paideia proposal: An educational manifesto. New York: Macmillan. https://doi.org/10.3726/978-1-4539-1735-0/25

Barry N., \& Raftery D. (2016). A new curriculum and a new learning space. In: Imms W., Cleveland B., Fisher K. (eds) Evaluating learning environments. Advances in learning environments research. Sense Publishers, Rotterdam https://doi.org/10.1007/978-94-6300-537-1_13

Duffy, B. (2006). Supporting creativity and imagination in the early years. London, New York: Oxford University Press.

Egan, K. (1997). The educated mind. how cognitive tools shape our understanding. Chicago: University of Chicago Press. https:// doi.org/10.7208/chicago/9780226190402.001.0001

Egan, K. (2005). An imaginative approach to teaching. Thousand Oaks, CA: Jossey-Bass.

Egan, K. (2011). Learning in depth: A simple innovation that can transform schooling. Chicago: University of Chicago Press. https://doi.org/10.7208/chicago/9780226190457.001.0001

Egan, K., Judson, G., \& Cant, A. (Eds.) (2014). Wonder-full education: The centrality of wonder in teaching and learning across the curriculum. New York: Routledge. https://doi.org/10.1007/s11191-014-9726-6

Gardner, H. (2011). The unschooled mind. how children think and how schools should teach. New York: Basic Books.

Girod, M., Rau, C., \& Schepige, A. (2003). Appreciating the beauty of science ideas: Teaching for aesthetic understanding. Science Education, 87, 574-587. https:// doi.org/10.1002/sce.1054

Hadzigeorgiou, Y. (1997). Relationships, meaning and the science curriculum. Curriculum and Teaching, 12, 83-89. https://doi.org/10.7459/ct/12.2.08

Hadzigeorgiou, Y. (2001). The role of wonder and 'romance' in early childhood science education le ro^le de l'E' merveillement et du'Roman'dans l'E' education scientifique des jeunes enf...International Journal of Early Years Education 9 (1), 63 69. https://doi.org/10.1080/09669760125442

Hadzigeorgiou, Y. (2002). A study of the development of the concept of mechanical stability in preschool children. Research in Science Education 32 (3), 373-391. https://doi.org/10.1023/a:1020801426075

Hadzigeorgiou, Y. (2005). On humanistic science education. Eric Document (ED506504). https://doi.org/10.7459/ept/27.2.07 
Hadzigeorgiou, Y. (2012). Fostering a sense of wonder in the science classroom. Research in Science Education, 42, 985-1005. https://doi.org/10.1007/s11165-011-9225-6

Hadzigeorgiou, Y. (2013). Imagination in science learning. in R. Gunstone (Ed.) Encyclopedia of Science Education. Springer. https://doi.org/10.1007/978-94-0076165-0_465-2

Hadzigeorgiou, Y. (2014). Reclaiming the value of wonder in science education. In K. Egan, A. Cant, \& G. Judson (Eds.), Wonder-full education: The centrality of wonder in teaching and learning across the curriculum, 40-66. New York: Routledge. https://doi.org/10.1007/s11191-014-9726-6

Hadzigeorgiou, Y. (2015). A critique of science education as socio-political action from the perspective of liberal education. Science \& Education, 24, 259-280. https://doi.org/10.1007/s11191-014-9728-4

Hadzigeorgiou, Y. (2016). Imaginative science education. The central role of imagination in science education. Cham, Switzerland, Springer International. https://doi.org/10.1007/978-3-319-29526-8_1

Hadzigeorgiou, Y. (2017). Implications of R.S. Peters' notion of 'cognitive perspective' for science education. Educational Philosophy and Theory, 49 (10), 1016-1028. https:// doi.org/10.1080/00131857.2016.1273088

Hadzigeorgiou, Y., \& Konsolas, M. (2001). Global problems in the curriculum: Toward a humanistic and constructivist science education. Curriculum $\mathcal{E}$ Teaching, 16, 2939. https://doi.org/10.7459/ct/16.2.04

Hadzigeorgiou, Y., \& Fotinos, N. (2007). Imaginative thinking and the learning of science. Science Education Review, 6, 15-22.

Hadzigeorgiou, Y., \& Stivaktakis, S. (2008). Encouraging involvement with school science. Journal of Curriculum $\mathcal{E}$ Pedagogy, 5, 138-162. https://doi.org/10.1080/15505170.2008.10411692

Hadzigeorgiou, Y., Anastasiou, L., Konsolas, M., Prevezanou B. (2009). A study of the effect of preschool children's participation in sensorimotor activities on their understanding of the mechanical equilibrium of a balance beam. Science Education 39 (1), 39-55. https://doi.org/10.1007/s11165-007-9073-6

Hadzigeorgiou, Y., \& Garganourakis, V. (2010). Using Nikola Tesla's story and experiments, as presented in the film the «Prestige», to promote scientific inquiry. Interchange, 41, 363-378. https:// doi.org/10.1007/s10780-010-9136-x

Hadzigeorgiou, Y. \& Schulz, R. M. (2014). Romanticism and romantic science: Their contribution to science education. Science \& Education, 23, 1963-2006. https://doi.org/10.1007/s11191-014-9711-0

Hadzigeorgiou, Y., Stamatis, P. (2017). How relevant is RS Peters' conception of education to science education? Interchange 48(1), 1-18. https://doi.org/10.1007/s10780-016-9294-6

Higgins B., Reid, H. (2017). Enhancing "conceptual teaching/learning" in a conceptbased curriculum http://dx.doi.org/10.1016/j.teln.2016.10.005

Hirst, P.H. (1974). Knowledge and the curriculum. London, Routledge.

Louis, S. (2008). Knowledge and understanding of the world in the early years foundation stage. London: David Fulton Publishing. https://doi.org/10.4324/9780203609514

Moulakis, A. (1994). Beyond utility: Liberal education for a technological age, University of Missouri Press, Columbia. https://doi.org/10.5860/choice.31-5030

Oakeshott, M. (1989). The voice of liberal learning: Michael Oakeshott on education, ed. T. Fuller, London: Yale University Press. https://doi.org/10.5860/choice.26-6391

Oakeshott, M. (1991). Rationalism in politics and other essays. new and expanded edition. Indianapolis: Liberty Fund.

Peters, R. S. (1973). Farewell to aims? London Educational Review, 2 (3), 1-4.

Peters, R. S. (1998). The justification of education. In P. Hirst \& P. White (Eds.), Philosophy of education 1, 207-230. New York: Routledge. 
Pugh, K. (2004). Newton's laws beyond the classroom walls. Science Education, 88, 182 196. https://doi.org/10.1002/sce.10109

Pugh, K. (2011). Transformative experience: An integrative construct in the spirit of Deweyan pragmatism. Educational Psychologist, 46, 107-121. https:// doi.org/10.1080/00461520.2011.558817

Pugh, K. (2017). Computers, cockroaches, and ecosystems: Understanding learning through metaphor. Charlotte, NC: Information Age Publishing inc.

Schulz, R. M. (2009). Reforming science education. Part 1: The search for a philosophy of science education. Science $\mathcal{E} \quad$ Education, 18, 225-249. https:// doi.org/10.1007/s11191-008-9167-1

Schulz, R. M. (2013). Philosophy of education and science education: A vital but underdeveloped relationship. In M. R. Matthews (Ed.), International handbook of research in history, philosophy and science teaching, 1259-1315. Dordrecht: Springer. https://doi.org/10.1007/978-94-007-7654-8_39

Vygotsky, L. (1978). Mind in society: The development of higher psychological processes. Cambridge, MA: Harvard University Press. https:// doi.org/10.2307/1421493

Vygotsky, L. (1997). The collected works of L.S. Vygotsky, 1, (Eds. Robert W. Rieber \& Aaaron S. Carton). New York: Springer. https://doi.org/10.1007/978-1-46155939-9

Zimlich S., L. (2017). Technology to the rescue: Appropriate curriculum for gifted students. International Journal of Learning, Teaching and Educational Research 16, 112. https://doi.org/10.26803/ijlter.16.9.1 